\title{
QURRENT ECONOMICISSUES-BKR
}

\section{Financial Stability in Emerging Economies in the Near Future}

\section{Fernando $\mathrm{d}$ Cardim de Carvalho*}

\begin{abstract}
Financial Stability in Emerging Economies in the Near Future has gone through a reversal of fate lately. In the aftermath of the financial crisis of $2007 / 8$, the group was considered to be the next frontier of expansion of world capitalism. Nowadays, most of the countries in the group are mired in difficulties and are seen as a threat to international economic stability rather than an engine of growth. In this comment, we explore some key fragilities that are recognized in emerging economies, particularly those related to the accumulation of private debt. The perspectives for the near future are proposed to illustrate Keynes's concept of true uncertainty and encourage the search for liquidity by wealth-holders worldwide.
\end{abstract}

Key words: Emerging Economies; Financial Fragility; Debt Accumulation

"Senior Pesearch Scholar, Levy Eonomics Institute of Bard College, and Emeritus Professor, Federal University of Ro de Janeiro. 
Almost ten years after the beginning of the American financial crisis that was transformed into the worst economic crisis modern world has known since the 1930s, the appreciation of emerging economies has changes dramatically. In 2008, when the Lehman Brothers' bankruptcy sent shock waves throughout the world, emerging economies were seen as a beacon of stability. To some important extent, of course, this view reflected the rise of China as a major economic player, leaving behind every other country but the United States. By some metrics, China was in fact in process of beating even the American economy. Any group of countries that included China, therefore, was fated to embody the hopes that the crisis could be contained and its effects minimized. But although China seemed to be engaged in an unstoppable push to growth, it was not an isolated case. Much less impressive, it wastrue, but still exhibiting a much more favorable dynamics than any developed economy, were the case of economies like those in the BRICSgroup (Brazil, Russia, India, China and South Africa). Brazil was a particularly cherished example of growth oum income distribution and prevalence of political democracy that contrasted favorably with India, with its deep social problems, Russia and China with their authoritarian regimes, and South Africa, mired in political and administrative problems that seemed to be unsurmountable.

At the beginning of 2016, the picture has dramatically changed, undoubtedly for the worse. China has decelerated its growth rates to about half of what they used to be, with important negative effects on its trade partners. Russia has suffered the impacts of the international sanctions imposed as a result of its intervention on Ukraine and of the fall in oil prices. India still maintains a healthy rate of growth but without generating the positive impacts on partners that China did. South Africa is still mired in the same kind of interminable political problems that have choked its economy for so long. No country has suffered such a wide reversal of fate, however, as Brazil. Orashing under the combined weight of a deep political crisis, a major corruption scandal involving all levels of government and a completely inept economic policy-making, the country switched from virtual stagnation to a major recession since 2014. No end is still in sight for the nightmare, even though the economy has given signs that some kind of cyclical bottom may have been reached in mid-2016.

In such a picture, one should not be surprised to see growing fears in all quarters that emerging countries may be moving into a danger zone which can ultimately cause them to crash, with potentially important negative repercussions on the world economy. The path to a crisis this time, however, seems to be different from what was usual among these countries.

For most of the Twentieth Century, developing economies, of which emerging countries are a subgroup, always met the limits to their attempts to grow in the form of external constraints. Dependent on imports of more advanced capital goods and some raw materials and other intermediate goods, developing economies had their fate tied to the performance of their exports. ${ }^{1}$ Even after industrialization policies had been extensively implemented in many developing countries, cyclical fluctuations and financial stability remained largely dependent on how changes in the international economy were reflected in those economies.

Keynesian economists study the international economy in a similar way they study national economies, emphasizing two elements. On the one hand, the international economy

\footnotetext{
${ }^{1}$ External constraints set limits to economic growth throughout the developing world. Asian countries, however, dealt with the need to remove these constraints in ways that were largely different from the ways chosen by, say, Latin American countries. Therefore, such œnstraints manifested themselves in different fashion in both areas, although it is undeniable that they were as important in one area as they were in the other.
} 
demands goods and services produced in a given economy (as well as supply some goods and services to that economy). The first element, thus, is how does the international economy contribute to the determination of aggregate demand for the output produced in a given economy. This, of course, has been a central element in development strategies adopted by East Asian countries, including China. It goes beyond the need to finance imports of goods and services that cannot be produced domestically, it uses the rest of the world as a destination of locally produced goods, increasing domestic profitability when domestic sources of demand could perhaps not be sufficient to support expanding production.

The other element of the international economy emphasized by Keynesian economists is the provision of liquidity in foreign currency. Nationals of an economy need foreign currency for largely the same reasons why they need domestic currency. There is a transactions demand for foreign currency to use it to import goods and services, as there is a speculative demand for money depending on the expectations national s have of future changes in relative interest rates as well as changes in exchange rates (when they float). Finally, there is a precautionary demand for foreign currency to cover unexpected needs or to enjoy unexpected opportunities. One important way the precautionary demand for foreign currency is manifested is in the accumulation of reserves.

Of course, foreign liquidity can be provided by selling goods and services or by selling assets or issuing liabilities. In the latter case, one has to worry about the fragility of financial portfolios, both of individual nationals and for the country as a whole. While currency accumulat ed from exports of goods and services does not entail liabilities to be honored in the future, access to finance resulting from selling assets or issuing liabilities does create commitments that have to be honored. Issuing liabilities implies increasing leverage. Fragility is strengthened if maturity and currency mismatches also characterize the financial position of individuals and of the country.

If we use this framework to examine the possible short term developments open to emerging economies we can see that perspectives in terms of aggregate demand are not bright. In fact, news is not good, although one cannot say that it is terribly bad either in the front of commercial opportunities for emerging economies. Advanced economies continue to exhibit, in year 8 of the Great Pecession, a picture of semi-stagnation. The economy is performing better in the United Sates than in Western Europe and Japan in 2016 until 2018 (see table 1, below). However, in all three major geographical areas, growth has been low and volatile. Good and bad news succeed each other in a framework of structural weakness that make up for a not very bright immediate future. Most certainly, the inability, for political reasons, of the three major actors to implement expansionary macroeconomic policies has deepened the contractionary tendencies still prevailing as a result of the shocks which occurred from 2007 to 2010.

This would not be so bad had China maintained the growth rates that it exhibited until about five or six years ago. From two-digit rates the country seems to have settled now in the range of $6 \%$ to $6.5 \%$ real growth, certainly not enough to revive the leading role that China played in the international economy in the not so distant past.

With the mediocre performance of the most important economies in the world, it should not come as a surprise that international trade growth has been, at most, lackluster and promises to continue like that. Deceleration of world economic growth means not only that the volume of sales tends to fall but also that prices of commodities tend to fall. China's reorientation of its growth strategy in favor of domestic consumption, in detriment of domestic investment and exports, reduces its demand for many types of commodities that are very important to emerging markets exporters, including countries like Brazil (iron ore and 
other metals) and Chile (copper). Demand for food, on the other hand, may be sustained amidst such changes, although most certainly at lower levels than expected in the recent past.

These developments are important to shape expectations as to the extent to which the international economy will support aggregate demand for emerging economies. The financial position of these countries is affected mostly by other reasons. Perhaps the most important of them is the increase in foreign debt issued by domestic businesses and, in relatively lower scale, by governments. Exceptionally low interest rates in the United States, Western Europe and Japan resulting from the adoption by central banks of quantitative easing policies have stimulated private fund managers and financial investors to look for better opportunities in emerging economic areas. Some emerging economies kept interest rates higher than others, but practically all of them practiced higher rates than those of advanced economies. Some governments in the developing world took advantage of these low rates to finance their fiscal deficits, but those funds were directed mostly to private borrowers. Foreign debt has piled up to an extent sufficiently high to worry financial markets about the probability of default, especially if monetary policies are actually reversed in countries like the United States, as has been expected for quite some time now. Rsing interest rates in the United States could compromise the position of private borrowers in emerging economies both by the direct financial cost in terms of interest and also in terms of the cost of foreign currencies, since emerging market monies are expected to lose their value in such a situation. The growth of private foreign debt in emerging economies is perhaps the great est threat to financial stability one can see at this point for the near future if world interest rates rise and exchange rate volatility increases.

One should notice that a crisis generated by external insolvency of private borrowers would be very different from the traditional crises of the past in emerging economies. It would not be rooted in current account imbalances. It would not be rooted in public debt accumulation either. This, of course, adds to the uncertainty about how it would be managed by local governments. In principle, private debts are not a public problem. Lenders, domestic or foreign, can go to the courts to try to recover their loans or to demand bankruptcy procedures against the borrowers. It is not a public problem, but it may certainly be a systemic problem, if insolvency is triggered by movements in international interest rates and/or in exchange rates. An attempt by the mass of borrowers to liquidate their foreign debts could lead to exchange rate devaluations that would create a contagion effect to other borrowers and, ultimately, to the whole business sector. Besides, such an exchange rate devaluation could create uncontrollable domestic inflationary pressures that would demand the intervention of the monetary authorities. How would governments then act in such a situation, at this point, is everybody's guess.

These risks are compounded by the worsening of difficulties in financial markets in some advanced economies. The situation of the Italian banking system is perhaps the most serious at the moment. Bad debts have been accumulated in such a large scale by Italian banks that the Italian government evaluates that only state support can stabilize the system. Nevertheless, such support would go against the rules to resolve bank problems recently set by the European Union and is likely to be vetoed by the European Commission increasing uncertainties not only as to the future of Italian banks but also as to its possible impacts on European and international financial markets. After years of close-to-zero interest rates set in the context of quantitative easing policies in the United States, Europe and Japan, financial markets are in disarray and banks are certainly the class of institutions that suffer more directly the impacts of these policies.

In sum, important fragilities have accumulated that could threaten financial and macroeconomic stability in emerging areas in the near future, independently of other 
weaknesses rooted in domestic problems, such as political and geopolitical crises. In themselves, these threats would be serious enough. They occur, however, within an adverse context of fragilities exhibited by financial markets also in advanced economies. We face a situation that Keynes would probably characterize as of true uncertainty: it is not so much the expectation that things will go bad that shape behaviors and decisions as the realization that one does not know how to attribute probabilities to the possible outcomes of the present situation. In such circumstances, however, the risk is that liquidity preferences are raised and interest rates rise because of the attempt of increasing number of financial investors to remain liquid to better manage what comes ahead. As Keynes reminded us many times, it is not possible for everybody to be liquid. When liquidity preferences rise sharply, the end result can only be a financial crisis.

Table 1. Growth, Trade, Capital Hows, and Prices

\begin{tabular}{|c|c|c|c|c|c|c|}
\hline PEALGDPGROWTH RATES & $(\%)$ & & & & & \\
\hline & 2013 & 2014 & 2015 & 2016 & 2017 & 2018 \\
\hline Advanced Economies & 2,4 & 2,6 & 2,4 & 2,4 & 2,8 & 3 \\
\hline USA & 1,5 & 2,4 & 2,4 & 1,9 & 2,2 & 2,1 \\
\hline 日U & $-0,3$ & 0,9 & 1,6 & 1,6 & 1,6 & 1,5 \\
\hline Japan & 1,4 & $-0,1$ & 0,6 & 5 & 0,5 & 0,7 \\
\hline Emerging and Developing Ecs. & 4,7 & 4,2 & 3,4 & 3,6 & 4,4 & 4,7 \\
\hline Commod.Exporters & 3,2 & 2,1 & 0,2 & 0,4 & 2,4 & 3 \\
\hline Other & 5,9 & 5,9 & 5,9 & 5,8 & 5,7 & 5,8 \\
\hline China & 7,7 & 7,3 & 6,9 & 6,7 & 6,5 & 6,3 \\
\hline Argentina & 2,9 & 0,5 & 2,1 & $-0,5$ & 3,1 & 3 \\
\hline Brazil & 3 & 0,1 & $-3,8$ & -4 & $-0,2$ & 0,8 \\
\hline Mexico & 1,4 & 2,3 & 2,5 & 2,5 & 2,8 & 3 \\
\hline India & 6,6 & 7,2 & 7,6 & 7,6 & 7,7 & 7,7 \\
\hline Russia & 1,3 & 1,7 & $-3,7$ & $-1,2$ & 1,4 & 1,8 \\
\hline World Trade & 3,3 & 3,8 & 3,1 & 3,1 & 3,9 & 4,1 \\
\hline \begin{tabular}{|l} 
Oil \\
Prices
\end{tabular} & $-0,9$ & $-7,5$ & $-47,3$ & $-25,7$ & 32,5 & 6,5 \\
\hline Other Commodity Prices & $-7,2$ & $-4,6$ & -15 & $-12,2$ & 10,5 & 2,3 \\
\hline \multicolumn{7}{|l|}{ Capital Inflowsto BMDE } \\
\hline (\% of GDP) & 5,4 & 4,3 & 1,8 & 3,2 & 3,8 & 4,2 \\
\hline Source: World Bank, Global E & omic Pr & ts, lun & & & & \\
\hline
\end{tabular}

